\title{
Adjuvant chemotherapy for resected earlier stage adenocarcinomas with unfavorable architecture. Should we incorporate histologic findings to the decision tree?
}

\author{
Eric Vallières, MD, FRCSC
}

From the Division of Thoracic Surgery, Swedish Cancer Institute, Seattle, Wash.

Disclosures: Author has nothing to disclose with regard to commercial support.

Received for publication Oct 30, 2017; accepted for publication Nov 11, 2017; available ahead of print Dec 6, 2017

Address for reprints: Eric Vallières, MD, FRCSC, Division of Thoracic Surgery, Swedish Cancer Institute, 1101 Madisson, Suite 900, Seattle, WA 98104 (E-mail: eric.vallieres@swedish.org).

J Thorac Cardiovasc Surg 2018;155:1236-7

0022-5223/\$36.00

Copyright (c) 2017 by The American Association for Thoracic Surgery

https://doi.org/10.1016/j.jtcvs.2017.11.026

Platinum-based adjuvant chemotherapy is considered the standard of care for the treatment of fully resected (R0) stages II and IIIA, as well as for larger $(\geq 4 \mathrm{~cm})$ stage IB non-small cell lung cancer. These recommendations followed the consecutive reporting of 4 randomized phase III trials in 2004, 2005, and 2006. ${ }^{1-4}$ Adjuvant chemotherapy was not shown to benefit patients with node-negative smaller tumors, although the number of such tumors in these 4 trials combined was quite small, in part by design. Some data actually suggested that it could be detrimental to give adjuvant chemotherapy in such a scenario. ${ }^{5}$ The randomization and stratification on these trials were based solely on the pathologic TNM status of the resected tumors.

In this issue of the Journal, Qian and colleagues ${ }^{6}$ from the Shanghai Chest Hospital suggest that one could consider offering adjuvant chemotherapy after resection of smaller ( $>3 \mathrm{~cm}$ but $\leq 4 \mathrm{~cm}$ ) node-negative adenocarcinomas that have a predominantly solid or micropapillary pattern. Although the data presented are retrospective and nonrandomized, this report adds to an emerging literature suggesting that in addition to the crude $\mathrm{T}$ and $\mathrm{N}$ descriptors we have used to determine candidacy for adjuvant chemotherapy, the architectural grading of pulmonary adenocarcinomas according to the 2011 International Association for the Study of Lung Cancer, American Thoracic Society, and European Respiratory Society classification helps identify tumors with a significantly worst prognosis, for which the risks of metastases and recurrence are very high.

The National Comprehensive Cancer Network nonsmall cell lung cancer treatment guidelines already suggest a consideration of adjuvant chemotherapy after the resection of smaller size stage IB non-small cell lung cancer when tumor factors such as a poor degree of differentiation, the presence of lymphovascular invasion, or visceral pleural

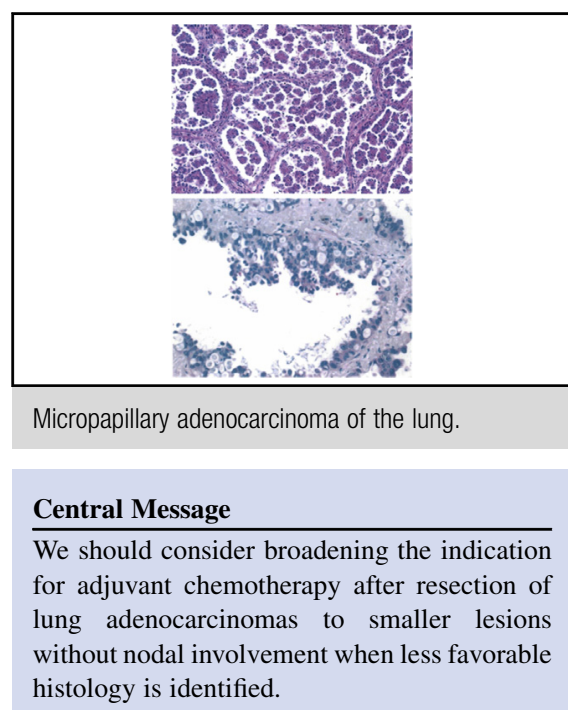

See Article page 1227.

involvement are identified. ${ }^{7}$ No randomized study has evaluated the role of adjuvant chemotherapy in the management of these high-risk tumors: it is accepted, however, that if the risks of recurrence are particularly high when one or more of these factors are identified, then the potential benefits of systemic chemotherapy may be worth the risks for the patient with good performance status.

Ideally, randomized phase III trials should evaluate whether adjuvant chemotherapy would benefit patients with smaller tumors without nodal involvement that harbor bad histologic features, including adenocarcinomas with predominant solid and micropapillary pattern. Such trials are unlikely to be completed in a timely fashion, however, considering how rapidly the systemic therapy landscape is evolving in the lung cancer world.

Finally, one has to remember that, in the trials that have helped us establish a role for adjuvant chemotherapy after good surgery, statistically the largest benefits were seen with the higher stage tumors ${ }^{5}$ : this is not because the drugs worked better in such scenarios but rather reflects the higher risks these tumors carried, such that one was more likely to see a benefit in the relatively small trials completed. Without randomized data to guide us, the decision could really come down to balancing in between the risks for 
failure and the safety and efficacy of the drugs that may help us prevent these failures.

\section{References}

1. Arriagada R, Bergman B, Dunant A, Le Chevalier T, Pignon JP, Vansteenkiste J; International Adjuvant Lung Cancer Trial Collaborative Group. Cisplatin-based adjuvant chemotherapy in patients with completely resected non-small-cell lung cancer. N Engl J Med. 2004;350:351-60.

2. Winton TL, Livingston R, Johnson D, Rigas J, Johnston M, Butts C, et al; National Cancer Institute of the United States Intergroup JBR.10 Trial Investigators. Vinorelbine plus cisplatin vs. observation in resected non-small-cell lung cancer. $N$ Engl J Med. 2005;352:2589-97.

3. Strauss GM, Herndon JE II, Maddaus MA, Johnstone DW, Johnson EA, Harpole DH, et al. Adjuvant paclitaxel plus carboplatin compared with observation in stage IB non-small-cell lung cancer: CALGB 9633 with the Cancer and Leukemia Group B, Radiation Therapy Oncology Group, and North Central Cancer Treatment Group Study Groups. J Clin Oncol. 2008;26:5043-51

4. Douillard JY, Rosell R, De Lena M, Carpagnano F, Ramlau R, GonzálesLarriba JL, et al. Adjuvant vinorelbine plus cisplatin versus observation in patients with completely resected stage IB-IIIA non-small-cell lung cancer (Adjuvant Navelbine International Trialist Association [ANITA]): a randomised controlled trial. Lancet Oncol. 2006;7:719-27.

5. Pignon JP, Tribodet H, Scagliotti GV, Douillard JY, Shepherd FA, Stephens RJ et al. Lung adjuvant cisplatin evaluation: a pooled analysis by the LACE Collaborative Group. J Clin Oncol. 2008;26:3552-9.

6. Qian F, Yang W, Wang R, Xu J, Wang S, Zhang Y, et al. Prognostic significance and adjuvant chemotherapy survival benefits of a solid or micropapillary pattern in patients with resected stage IB lung adenocarcinoma. J Thorac Cardiovasc Surg. 2018;155:1227-35.

7. Ettinger DS, Wood DE, Akerley W, Bazhenova LA, Borghaei H, Camidge DR et al; National Comprehensive Cancer Network. Non-small cell lung cancer, version 6.2015. J Natl Compr Canc Netw. 2015;13:515-24. 